ARH -2343

IIC-4, Chemistry

(TID 4500, 59th Ed.)

HYDROFLUORIC ACID SCRUBEER SYSTEMS

\title{
By
}

J. Vincent Panesko
Chemical Technology Laboratory Research and Development Chemical Processing Division

$$
\text { June } 1972
$$

Laboratory Work Performed by H. D. Merritt

\author{
ATLANTIC RICHFIELD HANFORD COMPANY \\ RICHLAND, WASHINGTON
}

\section{Approved for Public Rolases;}

Further Dissemination Unimited

d. D. Aardal 05/18/2011 

Page ABSTRACT . . . . . . . . . . . . . . . . ii i

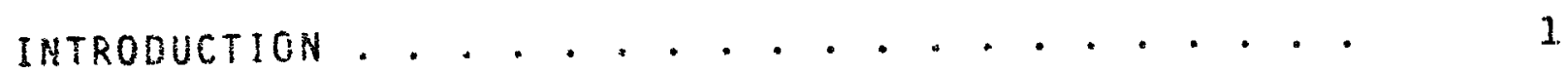
SUMmarr . . . . . . . . . . . . . . . . 1 EXPERIMENTAL .................. . . . . . . . 2 EQUIPMENT . . . . . . . . . . . . . . . 2 REAGENTS ................. . . . . . . 2 RESULTS RMD DISCUSSION.................. . . . 4 ABSORPTION OF HYDROFLUORIC ACID . . . . . . . 4 SOLIDS FORMATION WITH HYDROELUORIC ACID . . . . 5 ACKNOWLEDGMENTS ...................... . . . 7 REFERENCES.................... . . . . 7 


\section{ABSTRACT}

Caustic or aluminim scrubber solitions remove hicirogen jucride from off-gas streams. Solids whith appear with aluminum could be avoided by beating the serubber solution. 


\section{HYOROFLUORIC ACID SCRUBBER SYSTEMS}

\section{INTRODUCTION}

Each year sver a milion gallons of water are used to scxub hydrcgen fluoride (HF) vapors from waste off-gas streams. $[2,2]$ Use of other potential scrubbe: solutions such as potassium hydroxide (KOH), aluminum ititrate nonahydrate (ANN), and monciasic aluminum nitrate (monobani would result in significant volume reductions. A laboratory study was initiated to (1) demonstrate the effectiveness of these scrubber solutions to sorb HF, (2) determine if unexpected reactions occurred at flowsheet conditions, and (j) determine the consequences of deviation from flowsheet conditions.

\section{SUMMARY}

Caustic or aluminum scrubber solutions removed greater than $998 \mathrm{HF}$ from simulated off-gas streams. Two potential problem areas were observed:

- Rapid HF addition rates could increase the temperature of $\mathrm{KOH}$ to rear boiling.

- Solids appeared in aluminim scrutear solutions when the fluoride:aluminum molar latic exceeded 1.6 .

When the aluninum scrubber solutions were heated, a fluoride: aluminum molar ratio of 5.8 coula be achieved with no solids formation. 


\section{EXPERIMENTAL}

\section{EQUIPMENT}

An hF lecture bottle was warmed in a $50^{\circ} \mathrm{C}$ watct bath to vaporize 1iquid HE. Scrubber solutions were pumped at 30 Iitere/hour through a laboratory water aspirator jet which drew HF from the lecture bottle. The jet emptied into a 1-liter graduated cylinder from which scrubber solution was recycled tirough the pump and jet (see figure 1). A slight vacuum was placed on the graduatsd cylinder to draw unseacted if through a secondary scrubber containing caustic.

An AIF, precipitation study was performed by mixing different ratios of $F$ and $A 1$ in 250 -co glass bottles. When solids were obtained, they were filtered through a whatnan 42 filter, dried, and weighed.

\section{REAGEN'S}

Anhydrous hydrofluoric acid was obtained in a lecture bottle Irom Matheson Gas products. The bottle contained $31 / 41 b$ of 99.98 hydrofluoric acid. scrubber solutions were preparea by using Baker and Adamson reagent grade potassium hydroxide pellets, Chevron Chemical company $50 \%$ aluminumi nonahydrate solution, or Chevron Chemical company monobasic aluninum nitrate solution (monoban). The monobar \#as originally a 3.5 molar solution; rowever after standing for over a year, some crystallization had vocurred--reducing the molarity to near 3. Studies of solid formation at aifferent $F: A 1$ ratios used aliquots of $48 \%$ hydrogen fluoride (analyticai reagent from Mallinckrodt Chemical works) and the above aluminum solutions. 


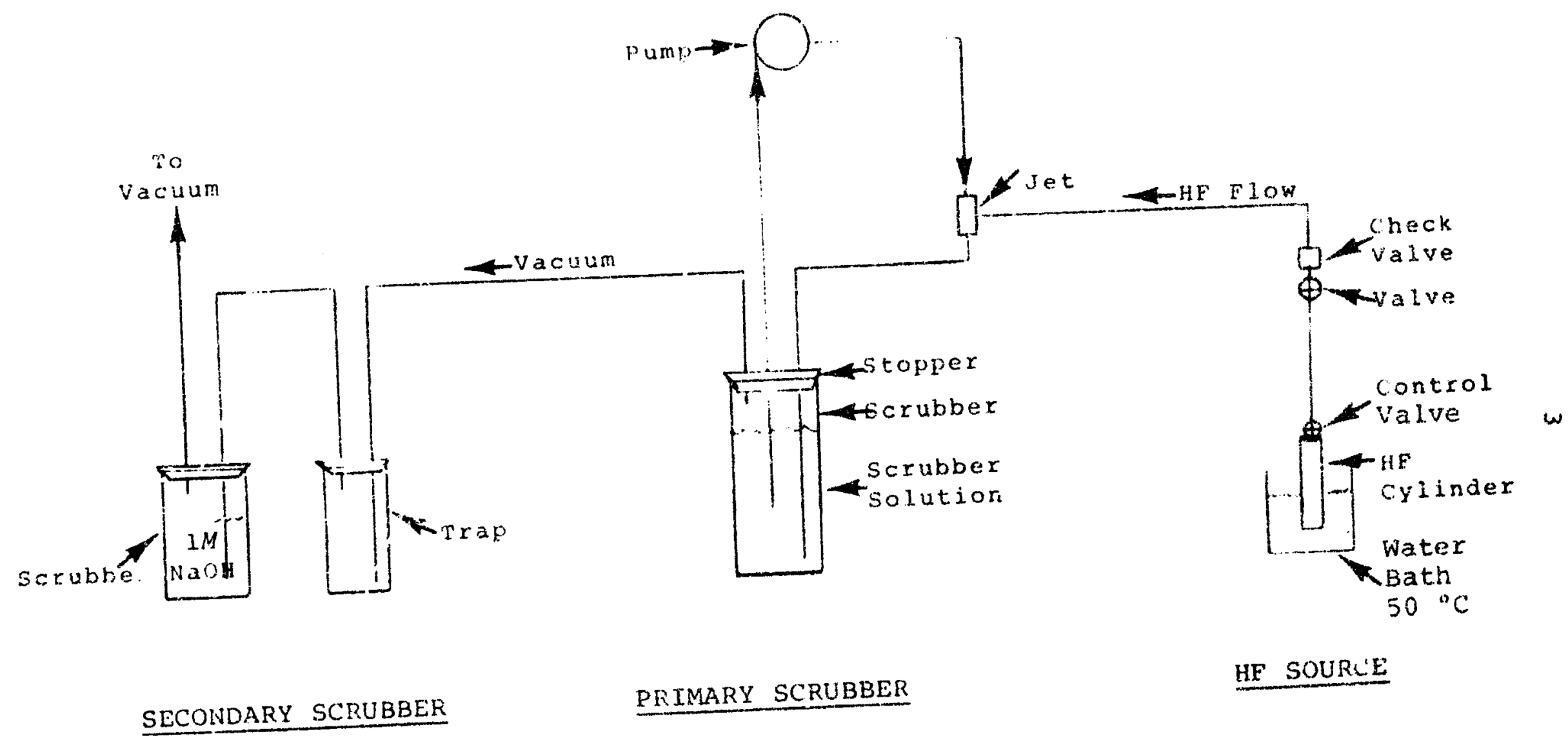

\section{FIGURE I}

HYDROFLUORIC ACIO SCRUBBER SYSTEM 


\section{RESULTS AND DISCUSSION}

ABSORPTION OF MYDROFIUORIC ACID

Eive runs were made with $5.45 \mathrm{M}$ KoH (see Table I).

TABLE I

ABSORPTION OF GASEOUS H.F

\begin{tabular}{|c|c|c|c|c|c|c|c|}
\hline \multirow[t]{2}{*}{ En } & $\frac{\text { Iane }}{\min }$ & $\begin{array}{l}\text { Sorubber } \\
\text { yolume } \\
\text { ILEers }\end{array}$ & $\begin{array}{c}\text { Initial } \\
\text { Moles }\end{array}$ & $\begin{array}{l}\text { Final } \\
\text { Moles }\end{array}$ & $\begin{array}{c}\text { HF } \\
\text { Added }= \\
\text { moles }\end{array}$ & Sempergture & 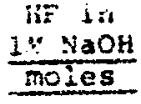 \\
\hline & \multicolumn{7}{|c|}{ Absorption with Kor } \\
\hline $\begin{array}{l}i \\
2 \\
3 \\
4 \\
\vdots\end{array}$ & $\begin{array}{l}30 \\
10 \\
20 \\
20 \\
15\end{array}$ & $\begin{array}{l}1 \\
1 \\
0.87 \\
0.5 \\
0.4\end{array}$ & $\begin{array}{l}5.45 \quad 104 ! \\
4.56 \\
0.75 \\
2.75 \\
0.09\end{array}$ & $\begin{array}{l}4.56 \text { lolli } \\
0.88 \\
0= \\
0.09 \\
0.0\end{array}$ & $\begin{array}{l}0.88 \\
3.63 \\
2.2 \\
2.5 \\
0.53\end{array}$ & $\begin{array}{c}3 i \\
- \\
6 \vdots \\
35\end{array}$ & $\begin{array}{l}0 \\
0.03 \\
0 \\
0 \\
0\end{array}$ \\
\hline \multicolumn{8}{|c|}{ MSsorption with MONOEA } \\
\hline 1 & 35 & 0.5 & 1.59 (A)) & - & 1.75 & $4 \%$ & 0 \\
\hline \multicolumn{8}{|c|}{ Absorption with ANiN } \\
\hline $\begin{array}{l}1 \\
? \\
3\end{array}$ & $\begin{array}{l}30 \\
60 \\
60\end{array}$ & $\begin{array}{l}1.0 \\
1.0 \\
1.0\end{array}$ & $\begin{array}{l}1.75 \\
1.75 \\
1.75\end{array}$ & $\overline{-}$ & $\begin{array}{l}1.7 \\
2.3 \\
2.4\end{array}$ & $\begin{array}{l}96 \\
40 \\
40\end{array}$ & 0 \\
\hline $\begin{array}{l}\dot{\vdots} \\
\vdots \\
\vdots\end{array}$ & $\begin{array}{l}\text { Determined } \\
\text { Determined } \\
p^{H}=6 \\
p ! 1=7 .\end{array}$ & $\begin{array}{l}\text { by titrat } \\
\text { by fif cyl }\end{array}$ & der weight & 1055. & & & \\
\hline
\end{tabular}

The first three runs used the same one liter of KoH at three different HF adaition rates $(0.033,0.36$, and 0.06 moles HF per liter per min, respectively). Run 2 resulted in excessive turbulence and a $50{ }^{\circ} \mathrm{C}$ temperature within 10 minutes. The heat of reaction for HF and KOH was calculated to be $-26.9 \mathrm{kcal} / \mathrm{mole} .[3,4]$ White HF fumes escaped from the primary $\mathrm{KOH}$ scrubber and were analyzed in the secondary NaOH scrubber. Runs 4 and 5 used 0.5 liter of fresh $5.45 \%$ KOH with HF addition rates of 0.25 and 0.15 moles per liter per min, respectively. The temperature of the $\mathrm{KOH}$ in Run 4 reached $60^{\circ} \mathrm{C}$ in $20 \mathrm{~min}$; the tempezature 
in Run 5 reached $35^{\circ} \mathrm{C}$ in $15 \mathrm{~min}$. Complete absorption of HF was demonstrated in all except Run 2 .

A single run showed that $3 \%$ monoban scrubber solution completely absorbed 0.12 moles HF per liter per minute. The scrubber solution temperature reached $45^{\circ} \mathrm{C}$ in $30 \mathrm{~min}$. The final fluoride:aluminum ratio was 1 (see rabie 1 ).

Three runs with one liter of 50 of AN (1.75\% Al) yielded increasing $5: A 1$ molar ratios of $i, 2.3$, and 3.6 . In the first run complete HF absorption occurred with a final temperature of $36^{\circ} \mathrm{C}$. When the $\mathrm{F}: \mathrm{Al}$ molar rat 10 reached 2.3. finely suspended solids were observed with no apparent loss in HF absorption. By the time the F:Al molar ratio reached 3.6, HF absorption was incomplete and a large amount of white, finely suspended solids slowed down reoirculation rates. Upon settling out, the solids formed a 20 volo jellylike nass which after two days required forceful stirring to break up.

\section{SOLIDS FORMATIOÑ WITH HYDROFLUORIC ACID}

Fluoride-to-aluminum molar ratios exceeding 1.6 yielded solids at room temperature (Table II). However, when the fiF wa: combined with ANN or monoban at $90^{\circ} \mathrm{C}$ and then cooled to room temperature, solids did not appear until an F:Al molar ratio of 1.9 vas exceeded. A solids-free soluticn with an F:A.1 ratio of 5.76 was obtained with a temperature of $90^{\circ} \mathrm{C}$. If the aluminum scrubber solution could be maintained at $90{ }^{\circ} \mathrm{C}$, then almost six moles of fluoride per cne mole of aluminum could be held in solution without solids formation. one of the previous scrubber runs indicated poor HF absorption with F:Al ratios of 3 to 4; however in that case the sarubber temperature was or $]_{y} A_{3}^{\circ} \mathrm{C}$ and solne $\mathrm{AlF} 3$ solids had formed. 
TABLE II

SOLIOS FORMATION AT DIFFERENT FLUORIDE-TO-ALUMINUH FATIOS

\begin{tabular}{|c|c|c|c|c|}
\hline $\begin{array}{l}\text { Scruk } \\
\text { sobution }\end{array}$ & Ityp & $\begin{array}{l}\text { F:Al Mole } \\
\text { Ratio }\end{array}$ & Observations & $\begin{array}{l}\text { Theo. } \\
\text { solids }\end{array}$ \\
\hline 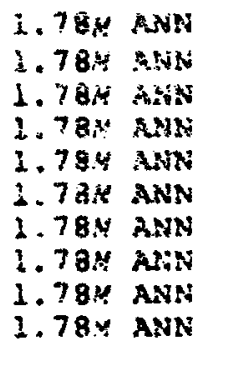 & $\begin{array}{l}25 \\
25 \\
25 \\
25 \\
25 \\
25 \\
25 \\
25 \\
25 \\
25\end{array}$ & $\begin{array}{l}0.96 \\
1.28 \\
1.6 \\
1.76 \\
1.92 \\
2.89 \\
3.84 \\
4.8 \\
5.76 \\
1.9\end{array}$ & $\begin{array}{l}\text { Clear. } \\
\text { Clear. } \\
\text { Clear. } \\
\text { Cloudy. } \\
\text { Trace solids. } \\
\text { Solids. } \\
\text { Some solids. } \\
\text { Some solids. } \\
\text { Some solids. } \\
\text { Solids at } 25^{\circ} \mathrm{C} \text {. clear whan neated } \\
\text { to } 90^{\circ} \mathrm{C} \text {. }\end{array}$ & $\begin{array}{r}0 \\
0 \\
0 \\
<5 \\
13 \\
82 \\
52 \\
44 \\
39\end{array}$ \\
\hline $\begin{array}{l}1.78 M \text { ANN } \\
2.78 M \text { ANN }\end{array}$ & $\begin{array}{l}90 \\
90\end{array}$ & $\begin{array}{l}1.9 \\
2.88\end{array}$ & $\begin{array}{l}\text { Clear, even afiar cooling to }-10 \text { " } \mathrm{C} \text {. } \\
\text { cledir, trace solids when cooled } \\
\text { overnight. }\end{array}$ & NM \\
\hline $\begin{array}{l}1.79 .4 \text { ANN } \\
1.79 .9 \text { ANN } \\
1.78 .2 \text { ARS: }\end{array}$ & $\begin{array}{l}90 \\
90 \\
90\end{array}$ & $\begin{array}{l}1.9 \\
1.9 \\
5.76\end{array}$ & $\begin{array}{l}\text { Gradual cool, no solids at } 22 " \mathrm{C} \\
\text { Rapid cool to } 22^{\circ} \mathrm{C} \text {, no solids. } \\
\text { Clear, gradual cool, solids } 50 \text { to } \\
\text { 7o } \mathrm{C} \text {. }\end{array}$ & NM \\
\hline 1.78 .4 ANN & 90 & 5.76 & $\begin{array}{l}\text { Clear, rapid cool, trace solias, more } \\
\text { with standing. }\end{array}$ & NH \\
\hline 1. $78 \%$ ANN & 90 & 1.9 & $\begin{array}{l}\text { Rapid cool, } 1 \text { part addad to } 10 \text { parts } \\
\text { CAN, no solids, } 22{ }^{\circ} \mathrm{C} \text {. }\end{array}$ & NM \\
\hline $1.78 \% \mathrm{ANN}$ & 90 & 5.76 & $\begin{array}{l}\text { Rapid nool, } 1 \text { part arded to } 10 \text { parts } \\
\text { CAW, no solids, } 22^{\circ} \mathrm{C} \text {. }\end{array}$ & NM \\
\hline $\begin{array}{l}-34 \text { MONOBAN } \\
\checkmark 3.4 \text { MONOBAN } \\
\checkmark 3 M \text { MONOBAN } \\
\sim 3 M \text { MONOBAN } \\
\sim 3 M \text { MONOBAN } \\
\because 3 M \text { MONOBAN }\end{array}$ & $\begin{array}{l}22 \\
22 \\
22 \\
22 \\
22 \\
22\end{array}$ & $\begin{array}{l}0.6 \\
1.1 \\
1.7 \\
2.3 \\
2.8 \\
3.4\end{array}$ & $\begin{array}{l}\text { Clear for weeks. } \\
\text { Clear for weeks. } \\
\text { Trace solids afiex } 3 \text { days. } \\
\text { Truce solids; slowly increase. } \\
\text { Solids, slowly increasr. } \\
\text { Solids, slowly increase. }\end{array}$ & $\begin{array}{l}0 \\
0 \\
0.6 \\
39 \\
54 \\
100\end{array}$ \\
\hline $\begin{array}{l}\imath 3 M \text { MONOSAN } \\
23 M \text { MOLOBAN } \\
23 M \text { MONOBAN } \\
\imath 3 M \text { MONOBAN }\end{array}$ & $\begin{array}{l}90 \\
90 \\
90 \\
90\end{array}$ & $\begin{array}{l}1.7 \\
1.7 \\
2.8 \\
2.8\end{array}$ & $\begin{array}{l}\text { Gradual cool, no solids. } \\
\text { Rapid cool, no solids. } \\
\text { Gadual cool, trace solids in } 4 \mathrm{hr} \text {. } \\
\text { Rapid cool, trace solids in } 4 \mathrm{rr} \text {. }\end{array}$ & $\begin{array}{r}0 \\
0 \\
10 \\
10\end{array}$ \\
\hline
\end{tabular}

- NM = not measined.

Disfoisl of the $90^{\circ} \mathrm{C}$ solution was a potential proplem because solids appeared when the temperature decreased to the 50 to $70^{\circ}$ range. This problem was solved by blending one part of $90^{\circ} \mathrm{C}$ scrubber soiution (F:Al $\left.=5.76\right)$ to 10 parts re a high-salt waste stream $(0.5$ to $1.04 \mathrm{Al})$. The combined solutions contained an excess of aluminum and yieldex a solids-free waste solutio at room temperature. 
Such a tich-aluninum waste stream was an ideal feed for fluidized bed calcination.

Monoban was commercially availabie in a higher concentration of aluminum (3.5M) than 508 ANN (1.75M Al). Thus the use of monoban would reauce the volume of scrubber solution for ultimate disposal.

\section{ACKNOWLEDGMENTS}

Appreciation is expressed to $G$. W. Upington loperations Support Engineering Department, Atlantic Richfield hanford Company) who suggested and assisted the 1969 HF scrubbing study; and to $M$. H. Curtis of the same group who suggested anc assisted the 1971 fluoride-aluminum ratio studies. Appreciation is also expressed to M. H. Campbell for editorial assistance and to Eleanore Earnart for secretarial aia. Current and past scrubber concepts including those studied in this report were summarized by $M$. H. Surtis in Reference 2 .

\section{REFERENCES}

1. G. Wpington, Personal Communication, Atlantic Richrield Hanford Company, Richiand, Washington, January 1969.

2. M. H. Curtis, Flowsheet-EZuorinator Off-Gae Eustem; AiN Recircilation Scrubber, AiH-2283, Atlantic RichEleld Hanford Company, Richland, Washington, December 15 , 1971.

3. G. B. King and W. E. Caldwell, coltege whemistre, 5th Edition, 1968, p. 210.

4. N. A. Lange, Hulwot of Chemistre, 9th Edition, 1956, p. 1577 . 


\section{DISTRIBUTION}

No. of Copies

56

delantic Richfield Hanford Company

D. G. Bouse

G. I. Borsheim

L. I. Brecke

M. H. Campbe 11 (5)

R. P. Corlew

M. H. Curtis

R. D. FOX

H. H. Hopkins, Ir.

W. P. Ingalis

R. E. Isaacson

L. M. Knights

J. P. Mcknight

D. I. Merxick

M. E. Muller

D. C. Nelson

G. A. Nicnolson

J. V. Panesko (1.5)

L. M. Fichards

A. E. Smith

P. W. Smith

J. A. Teal

G. W. Upington

J. H. Warren

ARHCO Document Services (2)

Extra (15)

5

Atomic Energy Comnission, Richland Operations office

O. J. Elgert

195

Atomic Energy Commission Technical

Information Center, Oak Ridge, Tennessee 